\title{
Intracellular pH Regulation and Proton Transport by Rabbit Renal Medullary Collecting Duct Cells Role of Plasma Membrane Proton Adenosine Triphosphatase
}

\author{
Mark L. Zeidel, Patricio Silva, and Julian L. Seifter \\ Departments of Medicine, Brigham and Women's Hospital and Beth Israel Hospital \\ and Harvard Medical School, Boston, Massachusetts 02115
}

\begin{abstract}
Proton secretion in the renal medullary collecting duct is thought to occur via a luminal proton-ATPase. In order to determine what mechanism(s) participate in proton transport across medullary collecting duct (MCD) cells membranes, intracellular pH (pHi) regulation and proton extrusion rates were measured in freshly prepared suspensions of rabbit outer MCD cells. Cells were separated by protease digestion and purified by Ficoll gradient centrifugation. $\mathrm{pH}_{\mathrm{i}}$ was estimated fluorometrically using the entrapped intracytoplasmic $\mathrm{pH}$ indicator, 6-carboxyfluorescein. Proton extrusion rates were measured using a pH stat. The resting $\mathrm{pH}_{\mathrm{i}}$ of $\mathrm{MCD}$ cells was $7.19 \pm 0.05$ (SE) in a nonbicarbonate medium of $\mathrm{pH} 7.30$. When cells were acidified by exposure to acetate salts or by abrupt withdrawal of ammonium chloride, they exhibited $\mathrm{pH}_{\mathrm{i}}$ recovery to the resting $\mathrm{pH}_{\mathrm{i}}$ over a 5-min timecourse. Depletion of $>\mathbf{9 5} \%$ of cellular ATP content by poisoning with $\mathrm{KCN}$ in the absence of glucose inhibited $\mathrm{pH}_{\mathrm{i}}$ recovery. ATP depletion inhibited proton extrusion from MCD cells. Treatment with $\mathrm{N}$-ethylmaleimide also inhibited $\mathrm{pH}_{\mathbf{i}}$ recovery. In addition, cellular ATP content was dependent on transmembrane pH gradients, suggesting that proton extrusion stimulated ATP hydrolysis. Neither removal of extracellular sodium nor addition of amiloride inhibited $\mathrm{pH}_{1}$ recovery. These results provide direct evidence that a plasma membrane proton-ATPase, but not a $\mathrm{Na}^{+}$/ $\mathrm{H}^{+}$exchanger, plays a role in proton transport and $\mathrm{pH}_{\mathrm{i}}$ regulation in rabbit MCD.
\end{abstract}

\section{Introduction}

The mammalian medullary collecting duct $(\mathrm{MCD})^{1}$ is thought to secrete hydrogen ions via a proton-ATPase on the luminal membrane. Evidence favoring this view is based on the similar properties of proton secretion in the reptilian urinary bladder and the collecting duct. Evidence for a central role of a luminal proton-ATPase in proton secretion in the turtle bladder includes the demonstration that proton secretion in this tissue is electro-

This paper was presented in part at the American Society of Nephrology meetings, Washington, DC, 1984, and was published in abstract form (1985. Kidney Int. 27:291).

Address correspondence to Dr. Seifter, Laboratory of Kidney and Electrolyte Physiology, Brigham and Women's Hospital.

Received for publication 31 May 1985.

1. Abbreviations used in this paper: $\mathrm{MCD}$; medullary collecting duct; MES, 2-[ $N$-morpholino]-ethanesulfonic acid; $\mathrm{pH}_{\mathrm{i}}$, intracellular $\mathrm{pH}$.

J. Clin. Invest.

(c) The American Society for Clinical Investigation, Inc.

$0021-9738 / 86 / 01 / 0113 / 08 \quad \$ 1.00$

Volume 77, January 1986, 113-120 genic (1), tightly coupled to cellular ATP content (2-5), inhibited by nonmitochondrial poisons $(5,6)$, and isolatable in a microsomal fraction that co-migrates with plasma membrane on sucrose gradients (6). In addition, proton secretion in the turtle bladder requires functional carbonic anhydrase (7) and is stimulated by mineralocorticoids $(7,8)$. In the MCD proton secretion has also been shown to be electrogenic (9), dependent on carbonic anhydrase (10), and stimulated by mineralocorticoid (11). In addition, a membrane-bound $\mathrm{H}^{+}$-ATPase similar to that of the turtle bladder has recently been purified from whole bovine medulla (12); there is no data as to the cellular location of this mammalian proton-ATPase fraction. Finally, the turtle bladder and mammalian medullary collecting tubule are morphologically similar, with both tissues comprised of principal and intercalated cells $(7,13)$. Metabolic and respiratory acidoses, which stimulate acid secretion in both bladder and MCD, provoke similar morphologic changes in the intercalated cells, but not in the principal cells of both systems (14-16).

The purpose of these experiments was to determine whether a plasma membrane proton ATPase plays a role in transmembrane proton flux and intracellular $\mathrm{pH}\left(\mathrm{pH}_{\mathrm{i}}\right)$ regulation in the mammalian MCD. We have therefore monitored $\mathrm{pH}_{\mathrm{i}}$ regulation and proton extrusion rates of cell suspensions isolated from rabbit MCD. In order to obtain a homogeneous cell population, we have isolated collecting duct cells from the inner stripe of the rabbit outer medulla. As will be discussed below, the inner stripe collecting duct consists almost entirely of principal cells and is known to engage in acidification $(11,13,17)$.

\section{Methods}

Isolation of medullary collecting duct cells. Collecting duct cells were isolated from the inner stripe of the outer medulla of male New Zealand white rabbits by a modification of the technique first reported by Eveloff et al. (18) for isolation of thick ascending limb cells. Male New Zealand rabbits were killed by cervical dislocation and exsanguinated via the carotid artery. The kidneys were perfused free of blood via the renal artery with $30 \mathrm{ml}$ ice-cold Joklik's minimal essential medium containing $10 \%$ fetal bovine serum. They were then perfused with $5 \mathrm{ml}$ of $0.2 \%$ collagenase and $0.25 \%$ hyaluronidase dissolved in the same medium. The inner stripes were excised from each kidney and finely minced. The minced outer medulla was incubated for $1 \mathrm{~h}$ in $0.2 \%$ collagenase and $0.25 \%$ hyaluronidase in Joklik's minimal essential medium at $37^{\circ} \mathrm{C}$ under $95 \% \mathrm{O}_{2} / 5 \% \mathrm{CO}_{2}$. The resulting digest was centrifuged twice at $75 \mathrm{~g}$ for 3 min to harvest the tubular segments. All centrifugations were performed in a Damon/IEC DPR 6000 swinging bucket centrifuge. The tubules were incubated for $20 \mathrm{~min}$ in $200 \mathrm{ml}$ of a $0.25 \%$ trypsin solution in Joklik's medium with $10 \%$ fetal bovine serum at room temperature under a $95 \% \mathrm{O}_{2} / 5 \% \mathrm{CO}_{2}$ gas phase. The tubule suspension was then centrifuged for $20 \mathrm{~s}$ at $700 \mathrm{~g}$ and the pellet containing undigested tubules returned to fresh trypsin solution. The supernatant was then centrifuged for 5 min at $300 \mathrm{~g}$ to collect the cells, which were then resuspended in $10 \mathrm{ml}$ of iced Joklik's medium with $10 \%$ fetal bovine serum. The trypsin diges- 
tion of the tubules was repeated seven more times and the cell harvests pooled. The pooled cells were washed again at $300 \mathrm{~g}$ for $5 \mathrm{~min}$, resuspended in Joklik's medium, and filtered through a 30-gauge teflon mesh. The resulting cell suspension was then layered over $60-\mathrm{ml}$ continuous Ficoll gradients $(5-46 \%)$ and centrifuged for $45 \mathrm{~min}$ at $2,300 \mathrm{~g}$. The Ficoll was dissolved in a buffer of the following composition: $137 \mathrm{mM}$ $\mathrm{NaCl}, 5 \mathrm{mM} \mathrm{KCl}, 0.33 \mathrm{mM} \mathrm{Na}_{2} \mathrm{HPO}_{4}, 0.44 \mathrm{mM} \mathrm{KH} \mathrm{PO}_{4}, 1 \mathrm{mM}$ $\mathrm{CaCl}_{2}, 2 \mathrm{mM} \mathrm{MgCl}_{2}, 0.8 \mathrm{mM} \mathrm{MgSO}_{4}$, and $20 \mathrm{mM}$ Tris- $\mathrm{HCl}, \mathrm{pH} 7.4$. $5 \mathrm{ml}$ of cell suspension were placed on each gradient. The gradients were harvested in 4-ml fractions for a total of 10 fractions. The cells were then washed free of Ficoll by using a 10-fold excess of Joklik's medium containing fetal bovine serum at $300 \mathrm{~g}$ for $10 \mathrm{~min}$. As described $(18,19)$, the MCD cells were located in the upper two fractions, the thick ascending limb cells in the lowest fraction. The MCD fraction contains cells that closely resemble MCD cells in situ by both light and electron microscopy (19). In addition, the MCD fraction was purified for both carbonic anhydrase and ADH-stimulated adenylate cyclase, two enzymes known to be present at high activity in medullary collecting duct (19). Finally, MCD cells exhibited oxidative metabolism distinct from that of the thick ascending limb cells (19).

Measurement of $\mathrm{pH}_{i}$. The medium used for all experiments was a nominally bicarbonate-free Ringer's composed of $\mathrm{NaCl}(130 \mathrm{mM}), \mathrm{KCl}$ (5 mM), Tris-Hepes (10 mM, pH 7.30), $\mathrm{MgSO}_{4}(0.4 \mathrm{mM}), \mathrm{CaCl}_{2}$ (2 mM), $\mathrm{Na}_{2} \mathrm{HPO}_{4}(2 \mathrm{mM})$, and unless specified, glucose ( $\left.5 \mathrm{mM}\right)$. Cells were resuspended in nonbicarbonate Ringer's and incubated for 15-20 min in $10 \mu \mathrm{M}$ 6-carboxyfluorescein diacetate at $25^{\circ} \mathrm{C}$ and an extracellular $\mathrm{pH}$ titrated to 6.5 by addition of concentrated 2-[ $\mathrm{N}$-morpholino]-ethanesulfonic acid (MES). The diacetate form of this dye rapidly enters the cells, where it is converted to the optically active 6-carboxyfluorescein by intracellular esterases (20-22). Once loaded with 6-carboxyfluorescein, cells were washed thoroughly to remove MES and extracellular dye. The fluorescence of the dye-loaded cells was monitored using a Perkin-Elmer model MPF44A fluorescence spectrophotometer equipped with temperature-controlled water jacket and a mechanical stirrer. Excitation wavelengths were 492 and $450 \mathrm{~nm}$ (slit $4 \mathrm{~nm}$ ) and emission wavelength was $530 \mathrm{~nm}$ (slit $10 \mathrm{~nm}$ ). Approximately one-million cells were diluted into $3 \mathrm{ml}$ of nonbicarbonate Ringer's and stirred in the fluorimeter at $37^{\circ} \mathrm{C}$. At the end of each run the cells were pelleted and the fluorescence of the supernatant assayed directly. By subtracting this extracellular signal from the total signal, the signal generated by the intracellular dye could be calculated.

Standard curves relating $\mathrm{pH}_{\mathrm{i}}$ and fluorescence excitation ratio were obtained by placing the cells in medium containing $137 \mathrm{mM} \mathrm{KCl}$ and adding the $\mathrm{K} / \mathrm{H}$ ionophore, nigericin $(20,22)$. Under these conditions, intracellular and extracellular $\mathrm{pH}$ were assumed to be equal; addition of small amounts of concentrated MES to the medium produced incremental acidification thus generating the curve. Fig. 1 shows a typical standard curve relating $\mathrm{pH}_{\mathrm{i}}$ (abscissa) and the fluorescence excitation ratio (1492/450; emission 530) for intracellular 6-carboxyfluorescein. It

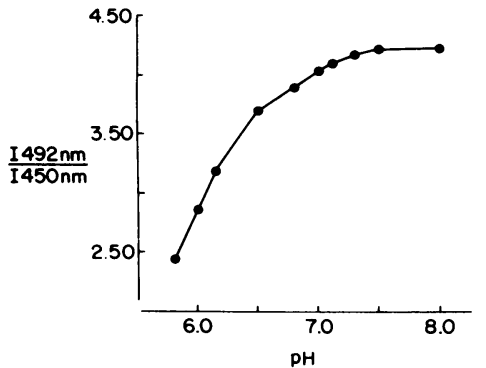

stepwise addition of $330 \mathrm{mM}$ MES (final concentration of $6.0=30 \mathrm{mM}$ ). At each $\mathrm{pH}$, the ratio of emission intensities obtained at excitation wavelengths 492 and $450 \mathrm{~nm}$ were measured. As described in Methods, the extracellular dye ratio was measured and subtracted from the total signal to give the signal generated by intracellular dye. is evident from the figure that the emission intensity generated by this excitation ratio increased considerably over the $\mathrm{pH}$ range, 6.0-7.5, allowing sensitive estimation of $\mathrm{pH}_{\mathrm{i}}$ in this range. Such standard curves were prepared daily; the fluorescence excitation ratios obtained from each run were compared with these standard curves to estimate the $\mathrm{pH}_{\mathbf{i}}$.

Measurement of proton extrusion. Proton efflux from MCD cells was measured using a Radiometer-Copenhagen $\mathrm{pH}$ stat equipped with a Model II titrator, an ABU 12 autobiuret, a Model $27 \mathrm{pH}$ meter, and an SBR 3 Titrigraph chart recorder mechanically coupled to the titrator. The titrant was $0.1 \mathrm{mM} \mathrm{NaOH}$. For $\mathrm{pH}$ stat experiments the Tris-Hepes and phosphate were omitted from the nonbicarbonate Ringer's. Twomillion cells were placed in $3 \mathrm{ml}$ of unbuffered nonbicarbonate Ringer's in a temperature-controlled chamber (Yellow Springs Instruments, Yellow Springs, $\mathrm{OH}$ ) equipped with a magnetic stirrer and $\mathrm{pH}$ electrode at $37^{\circ} \mathrm{C}$. The chamber was sealed from the atmosphere by a closely fitting plastic plunger equiped with a small port for additions of cells and solutions. The cells were titrated to the appropriate starting $\mathrm{pH}$ with dilute $\mathrm{NaOH}$ or $\mathrm{HCl}$. Generally, the cells were acid loaded by incubating them at extracellular pH of 6.5 for $5 \mathrm{~min}$. The extracellular $\mathrm{pH}$ was then abruptly raised to 7.40 by adding $\mathrm{NaOH}$. The rate of acid extrusion was measured as the rate of base equivalent addition required to maintain the extracellular $\mathrm{pH}$ at 7.40 as protons exited the cells. When cells were pretreated with cyanide, $2 \mathrm{mM} \mathrm{KCN}$ was also added to the unbuffered Ringer's, and the solution titrated to the desired $\mathrm{pH}$.

ATP measurements. ATP was measured using the firefly luciferase assay as described by Kimmich et al. (23). ATP was extracted by boiling the sample then pelleting the protein by centrifugation in a Sorvall RC$5 B$ centrifuge at $42,000 \mathrm{~g}$ for $20 \mathrm{~min}$. Cells were counted using standard hemocytometers. For experiments relating ATP levels to transmembrane proton gradients, MCD cells were washed free of glucose and resuspended in $1 \mathrm{ml}$ nonbicarbonate Ringer's titrated to $\mathrm{pH} 6.50$ with MES, to which was added $2 \mathrm{mM} \mathrm{KCN}$ and $0.5 \mathrm{mM}$ ouabain. After a 5-min incubation at pH 6.50 at $37^{\circ} \mathrm{C}, 0.3-\mathrm{ml}$ aliquots of cells were resuspended in $5 \mathrm{ml}$ of nonbicarbonate Ringer's with KCN and ouabain at pH 6.50 or 7.50 . Aliquots of these new suspensions were taken immediately and after 5 min at $37^{\circ} \mathrm{C}$ and extracted for ATP content.

Materials. Collagenase was obtained from Worthington Biochemicals, (Cooper Biomedical), Malvern, PA; hyaluronidase was obtained from Boehringer-Mannheim Biochemicals, Indianapolis, IN. Joklik's minimal essential medium was obtained from Gibco, Grand Island, NY; Ficoll was obtained from Pharmacia Fine Chemicals, Piscataway, NJ; and 6carboxyfluorescein diacetate was from Molecular Probes, Junction City, OR. All other reagents were obtained from Sigma Chemical Co., St. Louis, MO, and were of analytical grade. Firefly lanterns were obtained from Sigma Chemical Co., and homogenized to make a crude luciferase preparation (23). Digitonin was recrystallized three times and prepared as a 3-mM stock in dimethylsulfoxide.

Statistics. In all tables, a single $n$ represents the mean of duplicate or triplicate determinations of $\mathrm{pH}_{\mathrm{i}}$ recovery on a given cell preparation unless specified. Experimental results are given for the mean \pm SEM for at least three separate cell preparations, or are shown in a representative experiment. Groups were compared using unpaired $t$ tests; $P$ values $<0.05$ were regarded as significant.

\section{Results}

Acid-loading MCD cells. Fig. 2 shows the response of $\mathrm{pH}_{\mathrm{i}}$ to exposure of the cells to sodium acetate. The base-line resting $\mathrm{pH}_{\mathrm{i}}$ of MCD cells in bicarbonate-free Ringer's was 7.19 \pm 0.05 at an extracellular pH of $7.30(n=38)$. At time zero, acetate was added. Since the uncharged protonated form of this acid enters the cells far more rapidly than the acetate anion, the cells promptly acidified to $\mathrm{pH}_{\mathrm{i}}=6.50$ despite maintenance of a constant extracellular $\mathrm{pH}$. Over the next $7 \mathrm{~min} \mathrm{pH}_{\mathrm{i}}$ recovered, eventually reaching its resting value. To allow quantitative comparison of experimental groups, the first $3 \mathrm{~min}$ of the timecourse of $\mathrm{pH}_{\mathrm{i}}$ recovery was fitted to a linear equation of the form: $\mathrm{pH}_{\mathrm{i}}$ 


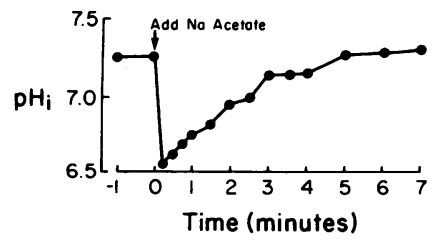

$\mathrm{mM} \mathrm{Na}$-acetate was added and the $\mathrm{pH}_{\mathrm{i}}$ monitored over the succeeding $7 \mathrm{~min}$. At each point, the fluorescence excitation ratio (492:450) was measured at emission wavelength $530 \mathrm{~nm}$ and the results compared with a standard curve similar to that shown in Fig. 1 to obtain estimates of $\mathrm{pH}_{\mathrm{i}}$.

$=k(t)+\mathrm{pH}_{\mathrm{i}(t=0)}$, where $k$ is the fitted constant describing the initial rate of $\mathrm{pH}_{\mathrm{i}}$ recovery, $t$ is the time after acid loading, and $\mathrm{pH}_{\mathrm{i}(t=0)}$ is the $\mathrm{pH}_{\mathrm{i}}$ at time zero. Correlation coefficients from these linear fits averaged 0.96 . Fitting the $\mathrm{pH}_{\mathrm{i}}$ recovery curves to a linear function relating $\mathrm{pH}_{\mathrm{i}}$ to time requires no assumptions regarding the mechanism(s) of $\mathrm{pH}_{\mathrm{i}}$ recovery, but merely introduces a straightforward means of quantitatively comparing experimental groups. A similar linearization was applied to proton efflux measurements of Ehrlich Ascites cells by Bowen and Levinson (24).

An additional method of acid-loading cells involves preincubation in weak bases such as ammonium salts followed by dilution into a medium that does not contain the weak base (25). Fig. 3 shows such a protocol involving exposure of MCD cells to $\mathrm{NH}_{4} \mathrm{Cl}$. In the top panel of this figure, $\mathrm{NH}_{4} \mathrm{Cl}$ was added to cells at time zero. Since the uncharged $\mathrm{NH}_{3}$ permeated the plasma membrane far more rapidly than the charged acidic form, $\mathrm{NH}_{4}^{+}$, the cells rapidly alkalinized. As first described by Boron and DeWeer (26), abrupt dilution of cells into ammonium-free medium resulted in the efflux of the more permeant $\mathrm{NH}_{3}$, leaving behind the more acidic $\mathrm{NH}_{4}^{+}$. Thus, as shown in the bottom panel of this figure, $\mathrm{pH}_{\mathrm{i}}$ fell rapidly upon ammonium withdrawal and then recovered gradually. As shown in the upper curve of the lower panel, the presence of extracellular ammonium prevented both the acidification and the recovery.

ATP depletion. To determine whether a plasma membrane proton-ATPase participates in the $\mathrm{pH}_{\mathrm{i}}$ recovery from both acidloading protocols described above, MCD cells were depleted of ATP. In glucose-containing nonbicarbonate Ringer's, at pH 7.30, MCD cells contained basal levels of ATP of $1.5 \pm 0.16 \mathrm{pm} /$ cell, a level comparable to that measured by Kimmich et al. (23) in intestinal epithelial cells using the luciferase method. As shown in Fig. 4, addition of $2 \mathrm{mM}$ potassium cyanide (KCN) to MCD cells in the presence of extracellular glucose resulted in only

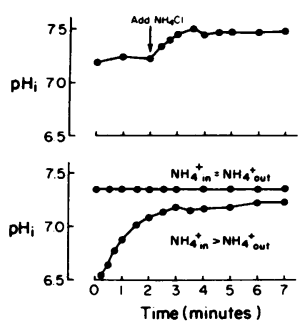

Figure 3. Time course of $\mathrm{pH}_{\mathrm{i}}$ after exposure to and withdrawal from $\mathrm{NH}_{4} \mathrm{Cl}$ solutions. Upper panel: $10^{6} \mathrm{MCD}$ cells preloaded with 6-carboxyfluorescein were placed in nonbicarbonate Ringer's. After measurement of resting $\mathrm{pH}_{\mathrm{i}}, 40 \mathrm{mM}$ $\mathrm{NH}_{4} \mathrm{Cl}$ was added to the suspension and the $\mathrm{pH}_{\mathrm{i}}$ monitored. Lower panel: $10^{6}$ MCD cells preloaded with 6-carboxyfluorescein were incubated for $15 \mathrm{~min}$ with $40 \mathrm{mM} \mathrm{HN}_{4} \mathrm{Cl}$ and then injected into $3 \mathrm{ml}$ of nonbicarbonate Ringer's in the fluorimeter containing no $\mathrm{NH}_{4} \mathrm{Cl}\left(\mathrm{NH}_{4 \text { in }}^{+}>\mathrm{NH}_{4 \text { out }}^{+}\right.$, lower curve) or $40 \mathrm{mM} \mathrm{NH}_{4} \mathrm{Cl}\left(\mathrm{NH}_{4 \text { in }}^{+}=\mathrm{NH}_{4 \text { out }}^{+}\right.$, upper curve).

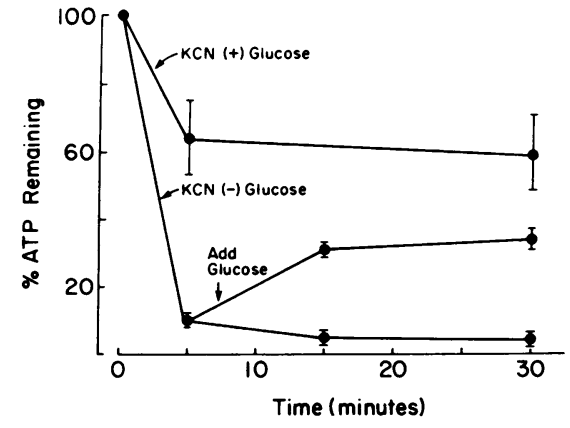

Figure 4. Effect of $\mathrm{KCN}$ in the presence and absence of glucose on cellular ATP content. MCD cells were exposed to $2 \mathrm{mM}$ potassium cyanide in the presence (upper curve) or absence (lower curve) of $5 \mathrm{mM}$ glucose at $37^{\circ} \mathrm{C}$. Immediately after addition of cyanide, aliquots of the cells were boiled and extracted for ATP (time zero). After 5 min of exposure to cyanide in the absence of glucose, some MCD cells were resuspended in $5 \mathrm{mM}$ glucose. Data represent mean \pm SE for triplicates performed on three separate preparations.

partial (30-40\%) depletion of cellular ATP content. In the absence of glucose, $>90 \%$ of ATP was rapidly depleted. Early addition of glucose to ATP-depleted cells restored a significant portion of cellular ATP. These results confirmed those of earlier studies demonstrating a high glycolytic capacity in medullary collecting duct (27), and provided a protocol for depleting these cells of ATP.

Effect of ATP depletion on $\mathrm{pH}_{i}$ recovery rate. Fig. 5 shows in a representative experiment the effect of ATP depletion on $\mathrm{pH}_{\mathrm{i}}$ recovery after acetate acid loading. In the top two panels, the $\mathrm{pH}_{\mathrm{i}}$ recovery rates of unpoisoned cells (control) and of cells exposed to $\mathrm{KCN}$ in the presence of glucose $(\mathrm{KCN}(+)$ glucose) are shown to be similar. By contrast, $\mathrm{pH}_{\mathrm{i}}$ recovery in cells depleted of ATP (KCN (-) glucose) was markedly inhibited. Some

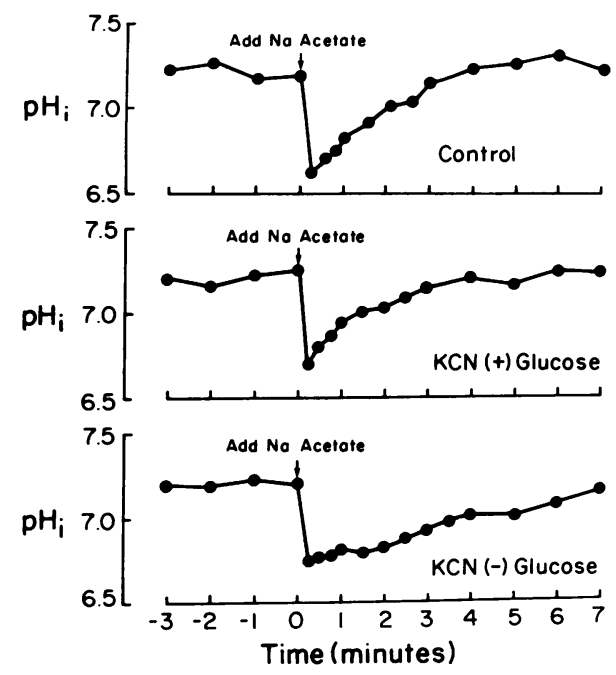

Figure 5. Effect of ATP depletion on $\mathrm{pH}_{\mathrm{i}}$ recovery after acetate acid loading. Protocol was as described in Fig. 2. Top: MCD cells in $5 \mathrm{mM}$ glucose, no cyanide. Middle: MCD cells preincubated $20 \mathrm{~min}$ in 2 $\mathrm{mM} \mathrm{KCN}$ in the presence of $5 \mathrm{mM}$ glucose; both $\mathrm{KCN}$ and glucose were present in the nonbicarbonate Ringer's used for the fluorimetry. Bottom: MCD cells preincubated $20 \mathrm{~min}$ in $2 \mathrm{mM} \mathrm{KCN}$ in the absence of glucose-medium in cuvette contains $\mathrm{KCN}$ but no glucose. 
of the more gradual recovery may have been due to slow uptake of acetate anions by these cells. In Table I, the results of all such experiments are given. The top row of this table shows that $\mathrm{pH}_{\mathbf{i}}$ recovery rate constant was similar for the unpoisoned cells and for cells poisoned in the presence of glucose $\left(2.5 \times 10^{-3} \mathrm{pH}\right.$ $\mathrm{U} / \mathrm{s}$ for control vs $2.25 \times 10^{-3}$ for $\mathrm{KCN}(+)$ glucose), but markedly diminished in cells poisoned in the absence of glucose $(1.10$ $\times 10^{-3}$ ). Since the resting $\mathrm{pH}_{\mathrm{i}}$ shown in the middle row was similar for all three experimental groups, the differences in $\mathrm{pH}_{\mathrm{i}}$ recovery rates could not have been due to initial $\mathrm{pH}$ differences. In addition, the fact that an identical acetate acid load provoked similar $\mathrm{pH}_{\mathrm{i}}$ drops as shown in the bottom row indicate that large differences in intracellular buffer capacity could not account for the observed differences in $\mathrm{pH}_{\mathbf{i}}$ recovery rates.

We next evaluated whether $\mathrm{pH}_{\mathrm{i}}$ recovery from a different acid-loading protocol, ammonium withdrawal, would also show a similar ATP dependence. As shown in Fig. 6, when MCD cells were poisoned with $\mathrm{KCN}$ in the presence or absence of glucose and acidified by the ammonium withdrawal protocol, the ATPdepleted cells recovered more slowly than their partially depleted counterparts. In addition, at the endpoint of most time courses, the $\mathrm{pH}_{\mathrm{i}}$ of the ATP-depleted cells failed to reach the resting $\mathrm{pH}_{\mathrm{i}}$. This experiment is representative of triplicate $\mathrm{pH}_{\mathrm{i}}$ timecourses performed on three separate cell preparations.

Role of extracellular sodium in $\mathrm{pH}_{i}$ regulation. In order to determine whether $\mathrm{Na}^{+} / \mathrm{H}^{+}$exchange plays a role in $\mathrm{pH}_{\mathrm{i}}$ regulation in MCD cells, we examined $\mathrm{pH}_{\mathrm{i}}$ recovery in the absence of extracellular sodium and in the presence of the pyrazine diuretic, amiloride, a known inhibitor of $\mathrm{Na}^{+} / \mathrm{H}^{+}$exchange (28). Fig. 7 shows, in a representative experiment, the effect of removing extracellular sodium on the rate of $\mathrm{pH}_{\mathrm{i}}$ recovery after an acetate acid load in MCD cells. It is clear that removal of extracellular sodium did not alter $\mathrm{pH}_{\mathrm{i}}$ recovery rate in these cells. When sodium was replaced with potassium to a final sodium concentration of 1-2 mM, the rate of $\mathrm{pH}_{\mathrm{i}}$ recovery was $2.45 \pm 0.43 \times 10^{-3} \mathrm{pH} \mathrm{U} / \mathrm{s}$ for low sodium, as compared with $2.60 \pm 0.35 \times 10^{-3}$ for normal sodium groups $(n=4)$. In addition,

Table I. Effect of ATP Depletion on $\mathrm{pH}_{i}$ Recovery after Acid Loading

\begin{tabular}{clll}
\hline & Control & $\begin{array}{l}\text { KCN } \\
\text { +Glucose }\end{array}$ & $\begin{array}{l}\text { KCN } \\
\text { - Glucose }\end{array}$ \\
\hline $\mathrm{pH}_{\mathrm{i}}$ recovery rate & & & \\
$\quad\left(\mathrm{pH} \mathrm{U} / \mathrm{s} \times 10^{3}\right)$ & $2.50 \pm 0.52(\mathrm{SEM})$ & $2.25 \pm 0.27$ & $1.10 \pm 0.13^{*}$ \\
$\mathrm{Resting} \mathrm{pH}_{\mathrm{i}}$ & $7.14 \pm 0.03$ & $7.12 \pm 0.05$ & $7.13 \pm 0.04$ \\
$\mathrm{pH}_{\mathrm{i}}$ drop $(\mathrm{pH} U)$ & $0.46 \pm 0.02$ & $0.44 \pm 0.05$ & $0.45 \pm 0.05$ \\
& $n=4$ & $n=5$ & $n=5$ \\
& & & \\
\hline
\end{tabular}

MCD cells preloaded with 6-carboxyfluorescein were placed in the fluorimeter and the resting $\mathrm{pH}_{\mathrm{i}}$ measured. After addition of $40 \mathrm{mM}$ $\mathrm{Na}^{+}$-acetate, the $\mathrm{pH}_{\mathrm{i}}$ rapidly fell and gradually recovered, as shown in Fig. 2 . The $\mathrm{pH}_{\mathrm{i}}$ recovery rate was determined as described in Methods. The $\mathrm{pH}_{\mathrm{i}}$ drop was measured as the difference in $\mathrm{pH}_{\mathrm{i}}$ between the resting $\mathrm{pH}_{\mathrm{i}}$ before acetate addition and the most acidic $\mathrm{pH}_{\mathrm{i}}$ reached after addition of acetate. Control cells were suspended in nonbicarbonate Ringer's with $5 \mathrm{mM}$ glucose present. $\mathrm{KCN}$ cells were poisoned with cyanide in the presence (+ glucose) or absence (- glucose) of glucose. Each $n$ represents duplicate or triplicate measurements of $\mathrm{pH}_{\mathrm{i}}$ recovery rate, resting $\mathrm{pH}_{\mathrm{i}}$, and $\mathrm{pH}_{\mathrm{i}}$ drop on a single $\mathrm{MCD}$ cell preparation. $* P<0.005$.

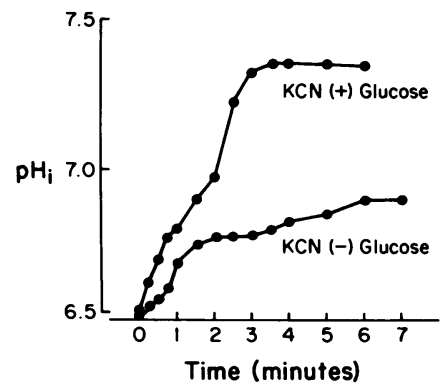

Figure 6. Effect of ATP depletion on $\mathrm{pH}_{\mathrm{i}}$ recovery after ammonium withdrawal. Cells were preloaded with 6-carboxyfluorescein and $40 \mathrm{mM} \mathrm{NH}_{4} \mathrm{Cl}$ as described in Fig. 3. In addition, cells were poisoned with $2 \mathrm{mM}$ $\mathrm{KCN}$ in the presence (upper curve) or absence (lower curve) of $5 \mathrm{mM}$ glucose. At time zero, $40 \mu$ l of concentrated cell suspension was injected into $3 \mathrm{ml}$ nonbicarbonate Ringer's containing $\mathrm{KCN}$ with (upper curve) or without (lower curve) glucose and $\mathrm{pH}_{\mathrm{i}}$ recovery monitored. This experiment is representative of duplicate or triplicate determinations performed on three different cell preparations.

in the presence of $\mathrm{Na}^{+}, 0.5 \mathrm{mM}$ amiloride did not alter the recovery rate, with control values of $3.31 \pm 0.71 \times 10^{-3} \mathrm{pH} \mathrm{U} / \mathrm{s}$ as compared with $3.32 \pm 0.68 \times 10^{-3}$ for the amiloride-treated cells $(n=3)$. In both the cation replacement and amiloride treatment experiments, the resting $\mathrm{pH}_{\mathrm{i}}$ and $\mathrm{pH}_{\mathrm{i}}$ drops were comparable between experimental groups. Taken together, these observations indicate that $\mathrm{Na}^{+} / \mathrm{H}^{+}$exchange does not play a significant role in $\mathrm{pH}_{\mathrm{i}}$ regulation in this preparation.

Inhibitor sensitivity of $\mathrm{pH}_{i}$ recovery. Since $\mathrm{Na}^{+} / \mathrm{K}^{+}$-ATPase also requires ATP, the inhibition of $\mathrm{pH}_{\mathrm{i}}$ recovery observed in cells depleted of ATP might have been due to inhibition of this enzyme. We therefore monitored $\mathrm{pH}_{\mathrm{i}}$ recovery in the presence and absence of ouabain. As shown in Table II, when MCD cells were exposed to $0.5 \mathrm{mM}$ ouabain for time periods similar to those used to poison the cells with $\mathrm{KCN}$, no significant alteration in the rate of $\mathrm{pH}_{\mathrm{i}}$ recovery was observed (top row, left panel). These results indicate that the inhibition of $\mathrm{pH}_{\mathrm{i}}$ recovery observed in ATP-depleted cells could not have been caused by inhibition of the $\mathrm{Na}^{+} / \mathrm{K}^{+}$-ATPase.

The right panel of Table II shows the effect of $\mathrm{N}$-ethylmaleimide on $\mathrm{pH}_{\mathrm{i}}$ recovery of MCD cells. This nonspecific sulfhydryl reagent, which is known to inhibit proton-ATPases in a number of tissues $(12,29)$, produced a statistically significant $30-40 \%$ inhibition of $\mathrm{pH}_{\mathrm{i}}$ recovery in MCD cells. In all experiments shown in this table, both resting $\mathrm{pH}_{\mathbf{i}}$ (middle row) and acetateinduced $\mathrm{pH}_{\mathrm{i}}$ drop (bottom row) were not different between control and experimental groups.

Effect of ATP depletion on cellular proton extrusion. To determine whether the observed changes in $\mathrm{pH}_{\mathrm{i}}$ recovery rate were caused by transmembrane proton flux or by intracellular buff-

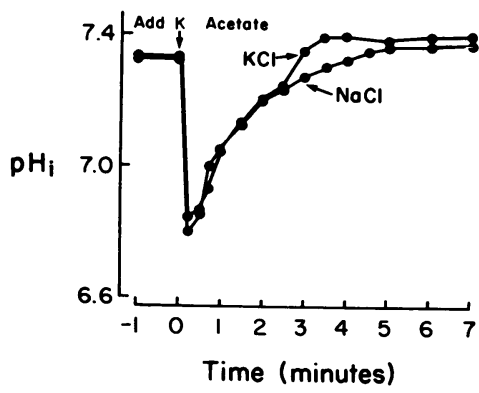

Figure 7. Effect of removal of extracellular sodium on $\mathrm{pH}_{\mathrm{i}}$ recovery after acetate acid load. MCD cells were washed and resuspended in $\mathrm{KCL}$ medium and then suspended in $\mathrm{KCl}$ or standard nonbicarbonate Ringer's $(\mathrm{NaCl})$ media. After measurement of resting $\mathrm{pH}_{\mathrm{i}}, 40$ $\mathrm{mM}$ potassium acetate was added and the $\mathrm{pH}_{\mathrm{i}}$ recovery monitored. The data are representative of duplicate or triplicate determinations performed with four batches of cells. 
Table II. Effect of Inhibitors on $\mathrm{pH}_{i}$ Recovery

\begin{tabular}{lllll}
\hline & Control & Ouabain $(0.5 \mathrm{mM})$ & Control & $N$-ethylmaleimide $(1 \mathrm{mM})$ \\
\hline $\mathrm{pH}_{\mathrm{i}}$ recovery rate $\left(\mathrm{pH} \mathrm{U} / \mathrm{s} \times 10^{3}\right)$ & $2.95 \pm 0.52$ (SEM) & $2.68 \pm 0.47$ & $3.27 \pm 0.71$ & $2.03 \pm 0.52^{*}$ \\
${\mathrm{Resting} \mathrm{pH}_{\mathrm{i}}}_{\mathrm{pH}_{\mathrm{i}} \text { drop }(\mathrm{pH})}$ & $7.22 \pm 0.08$ & $7.27 \pm 0.07$ & $7.22 \pm 0.05$ & $7.20 \pm 0.10$ \\
& $0.54 \pm 0.02$ & $0.52 \pm 0.07$ & $0.53 \pm 0.05$ & $0.48 \pm 0.05$ \\
& $n=4$ & $n=4$ & $n=4$ & $n=4$
\end{tabular}

$\mathrm{pH}_{\mathrm{i}}$ recovery rate, resting $\mathrm{pH}_{\mathrm{i}}$, and $\mathrm{pH}_{\mathrm{i}}$ drop were measured as described in Methods and Table $\mathrm{I}$. The control experiments for each inhibitor were performed on the same MCD cell preparations. Cells treated with inhibitors were poisoned for $15-60$ min before measurement of $\mathrm{pH}_{\mathrm{i}}$. $* P<0.01$.

ering, we measured cellular proton extrusion directly using a pH stat. Fig. 8 shows a representative control experiment designed to demonstrate that the $\mathrm{pH}$ stat method measures transmembrane proton flux. The cells were incubated for $5 \mathrm{~min}$ at an extracellular $\mathrm{pH}$ of 6.60 . The medium was then abruptly alkalinized by addition of concentrated $\mathrm{NaOH}$ to $\mathrm{pH} 7.40$ and the titrator started (lower curve). The ordinate represents the amount of base equivalents added by the titrator to the extracellular medium to maintain the $\mathrm{pH}$ at 7.40 . When the rate of base addition (as indicated by the slope of the line) had reached zero, $7 \mu \mathrm{M}$ digitonin was added to permeabilize the plasma membrane. The acid release provoked by this detergent confirmed the earlier finding that the resting $\mathrm{pH}_{\mathrm{i}}$ of these cells is more acidic than the extracellular $\mathrm{pH}$. Addition of digitonin in the absence of cells had no effect on the extracellular $\mathrm{pH}$. When the medium surrounding these same permeabilized cells was again acidified to $\mathrm{pH} 6.60$, and abruptly alkalinized to $\mathrm{pH} 7.40$ (upper curve), the rate of acid release from the cells to the extracellular solution was far more rapid than before permeabili-

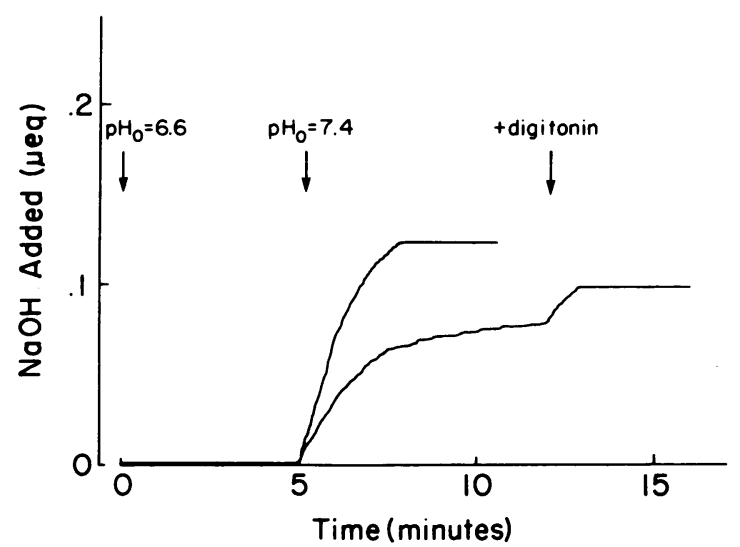

Figure 8. pH stat measurement of proton efflux from MCD cells. Two-million MCD cells were washed and resuspended in unbuffered nonbicarbonate Ringer's, placed in the $3 \mathrm{ml} \mathrm{pH}$ stat cell, and titrated to extracellular $\mathrm{pH}=6.60$. After $5 \mathrm{~min}$ at this $\mathrm{pH}$, a small volume of $1 \mathrm{M} \mathrm{NaOH}$ was added to abruptly raise the $\mathrm{pH}$ of the external solution to 7.40. The titrator was then started and added $0.1 \mathrm{mM} \mathrm{NaOH}$ at a rate sufficient to maintain the extracellular $\mathrm{pH}$ at 7.40 (lower curve). At $t=12 \mathrm{~min}, 7.5 \mu \mathrm{M}$ digitonin was added and the titrator restarted. At $t=17 \mathrm{~min}$, the extracellular $\mathrm{pH}$ was again adjusted to pH 6.6 and the chart recorder reset to the origin. After 5 min, concentrated $\mathrm{NaOH}$ was again added to raise the extracellular $\mathrm{pH}$ to 7.40 and the titrator again turned on (upper curve). This figure is representative of three similar runs at acidic pH's 6.50-6.70 and alkaline pH's 7.25-7.50 performed on three different cell preparations. zation. Since permeabilization of the plasma membrane markedly increased the rate of proton flux, the addition of base equivalents by the pH stat must have been a measure of the rate of proton flux across the plasma membrane.

Fig. 9 shows the effect of ATP depletion on transmembrane proton flux. In the absence of cellular ATP, protons were extruded far more slowly than when ATP was present. In addition, less net acid was extruded by the ATP-depleted cells. Since glycolysis generates acid, it was possible that the presence of glucose stimulated proton efflux by increasing glycolytic proton generation rather than by increasing cellular ATP levels (upper curve of Fig. 9). The effect of anaerobic glycolysis on proton extrusion at constant extracellular $\mathrm{pH}$ is shown in Fig. 10. Addition of glucose to glucose-starved $\mathrm{KCN}$ treated cells (curve A) produced a measurable stimulation of acid extrusion, presumably as a result of stimulating glycolysis. The rate of this proton afflux is $<20 \%$ of that observed when cells were acid loaded and abruptly returned to an alkaline medium (Fig. 9). Basal acid extrusion by cells poisoned with $\mathrm{KCN}$ in the presence of glucose (curve B) was barely measurable, even with the expanded ordinate and condensed timescale used in this figure. These results demonstrate that the more rapid rate of cellular proton extrusion observed in the presence of glucose was not caused by increased glycolytic proton generation in these cells.

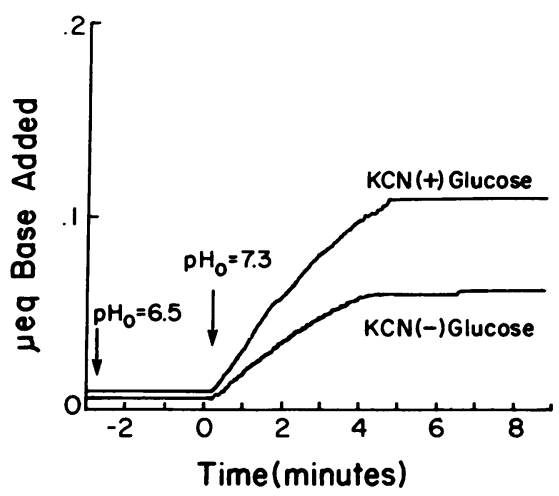

Figure 9. Effect of ATP depletion on proton extrusion after mineral acid loading. pH stat protocol as described in Fig. 8. MCD cells were incubated at $\mathrm{pH} 6.50$ for $5 \mathrm{~min}$, then the extracellular medium alkalinized to $\mathrm{pH} 7.3$ at $t=0$. Upper curve represents cells pretreated with 2 $\mathrm{mM} \mathrm{KCN}$ in the presence of $5 \mathrm{mM}$ glucose $(5 \mathrm{mM}$ glucose and $2 \mathrm{mM}$ $\mathrm{KCN}$ present in the $\mathrm{pH}$ stat medium). Lower curve represents cells pretreated with $2 \mathrm{mM} \mathrm{KCN}$ in the absence of glucose $(2 \mathrm{mM} \mathrm{KCN}$ present in the $\mathrm{pH}$-stat medium with no glucose). The figure is representative of duplicate or triplicate determinations performed on four cell preparations. 


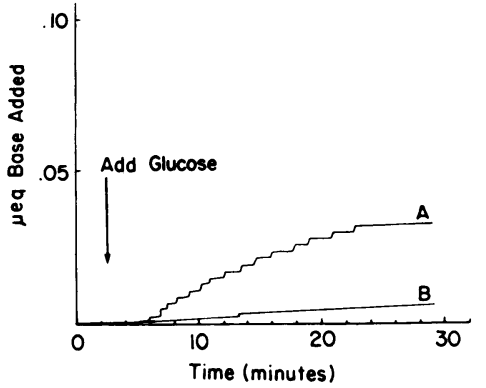

Figure 10. Effect of anaerobic glycolysis on proton extrusion. Curve A: Cells were poisoned with $\mathrm{KCN}$ in the absence of glucose and placed in the $\mathrm{pH}$ stat. At the arrow, $5 \mathrm{mM}$ glucose was added. Curve B: Cells were poisoned with $\mathrm{KCN}$ in the presence of $5 \mathrm{mM}$ glucose and placed in the $\mathrm{pH}$ stat to determine the steady state rate of proton extrusion. Note that the ordinate and abscissa of this figure differ from those of Figs. 8 and 9. The figure is representative of duplicate determinations performed on three cell preparations.

Effect of transmembrane pH gradients on cellular ATP content. In order to determine the effect of transmembrane $\mathrm{pH}$ gradients on cellular ATP content, MCD cells were depleted of ATP by poisoning with $\mathrm{KCN}$ in the absence of glucose in a solution of $\mathrm{pH}$ 6.50. After diluting cells into medium of $\mathrm{pH} 6.50$ or 7.30, aliquots were extracted immediately or after $5 \mathrm{~min}$ of incubation at $37^{\circ} \mathrm{C}$. The depletion of ATP was larger in acidloaded cells diluted into alkaline medium than in cells maintained in medium of constant acid pH. As shown in Fig. 11, cells kept at $\mathrm{pH} 6.50$ retained $24 \% \pm 0.04$ more ATP than cells alkalinized to pH $7.30(P<0.02$, paired $t$ test; $n=4)$. The results represent triplicate ATP extractions and assays performed on four different MCD cell preparations. These experiments were performed in the presence of $0.5 \mathrm{mM}$ ouabain, to prevent consumption of ATP by the $\mathrm{Na}^{+} / \mathrm{K}^{+}$ATPase. These results are consistent with the presence of an ATP-consuming acid extrusion mechanism such as a proton-ATPase in these cells. It is also possible that alkalinizing the cell interior enhanced ATP degradation by ATPases other than the plasma membrane proton-ATPase.

\section{Discussion}

Intracellular $\mathrm{pH}$ plays a critical role in volume regulation (30), cell growth (31), the actions of some hormones (33), and the regulation of many metabolic processes (31). Since the $\mathrm{pH}_{\mathrm{i}}$ measured in most cells is $6.90-7.50$ (25), values considerably higher

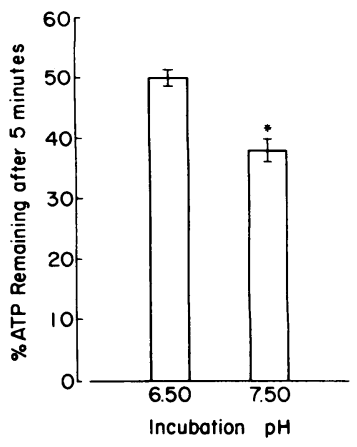

Figure 11. Effect of extracellular $\mathrm{pH}$ on cellular ATP content. MCD cells were washed free of glucose and resuspended in nonbicarbonate Ringer's titrated to $\mathrm{pH} 6.50$ with MES, to which was added $2 \mathrm{mM} \mathrm{KCN}$ and $0.5 \mathrm{mM}$ ouabain. After 5 min at pH 6.50 at $37^{\circ} \mathrm{C}$, aliquots of cells were resuspended in nonbicarbonate Ringer's with $\mathrm{KCN}$ and ouabain at $\mathrm{pH} 6.50$ or 7.50. Aliquots of these new suspensions were extracted for ATP content at time zero and after $5 \mathrm{~min}$ at the new pH. ATP contents for the 5-min timepoints are expressed as the percentages of ATP present at time zero remaining at $5 \mathrm{~min} . P<$ 0.02 , paired $t$ test; $n=4$ than the $\mathrm{pH}_{\mathrm{i}}$ predicted for electrochemical equilibrium, cells must have proton transport mechanisms capable of extruding protons against their electrochemical gradient. Such proton secretory mechanisms include $\mathrm{Na}^{+} / \mathrm{H}^{+}$exchange (proximal tubule, lymphocytes, cultured cell lines) and plasma membrane protonATPases (turtle bladder mitochondrion-rich cells, gastric oxyntic cells, bacteria) $(25,30-32)$. In epithelial cells specialized to transport acid, these proton extruding mechanisms may be used to remove net acid from the organism. We have examined $\mathrm{pH}_{\mathrm{i}}$ recovery and acid extrusion by cells of one such acid-secreting epithelium, the MCD, in order to determine which mechanism(s) might acount for proton transport in this segment.

Measurement of $\mathrm{pH}_{\mathrm{i}}$ has been accomplished by a number of methods including intracellular electrodes, the distribution of weak acids or bases (e.g., dimethyloxazolidine-2,4-dione [DMO] and Acridine Orange), or by the use of $\mathrm{pH}$-sensitive intracellular dyes such as 6-carboxyfluorescein $(20,25)$. Although electrodes measure $\mathrm{pH}_{\mathrm{i}}$ most accurately, most mammalian cells are too small for technically satisfactory recordings. The weak acids and bases distribute into all cell compartments, including relatively alkaline mitochondria and acidic lysosomes, and thus do not measure directly the $\mathrm{pH}$ adjacent to the plasma membrane (25). In addition, the prolonged period required for equilibration of these indicators in many cell systems (33) precludes their use for the study of rapid changes in $\mathrm{pH}_{\mathrm{i}}$. By contrast, 6-carboxyfluorescein has been shown in a number of cell types to distribute almost exclusively in the compartment of greatest interest in the study of transmembrane proton transport, the cytoplasm $(20-22)$. Since this dye is preloaded into the cells before the experiment, there is no delay in measurement of $\mathrm{pH}_{\mathrm{i}}$ while the dye distributes. We have therefore measured the fluorescence of cell suspensions preloaded with 6-carboxyflourescein in order to estimate resting $\mathrm{pH}_{\mathrm{i}}$ and to monitor changes in $\mathrm{pH}_{\mathrm{i}}$. Although in the present study the actual value of $\mathrm{pH}_{\mathrm{i}}$ is of less importance than the changes observed during acid-loading and recovery, the value of 7.19 measured for MCD cells in bicarbonate-free medium at external $\mathrm{pH}$ of 7.30 is entirely consistent with resting $\mathrm{pH}_{\mathrm{i}}$ observed in a variety of cell systems using a variety of methods (25). In addition, the relative acidity of the intracellular space compared with the extracellular medium at external pH 7.257.5 was confirmed on the pH stat using digitonin (Fig. 8).

The cell suspensions used in these experiments express morphologic and enzymatic characteristics of the inner stripe of the outer medullary collecting duct. Their viability has been confirmed by measurement of $\mathrm{O}_{2}$ consumption, ATP levels (19), and, in this study, by the demonstration of $\mathrm{pH}_{\mathrm{i}}$ regulation. In the outer medulla, the collecting duct is composed of two cell types, the principal and intercalated cells. In our suspensions, we find only principal cells (19). This result can be explained by the fact that in the rabbit medulla the proportion of intercalated cells diminishes gradually from $\sim 50 \%$ at the corticomedullary junction to $0 \%$ in the papilla (13). In the outer stripe and in the cortex, collecting duct acid secretion is thought to occur only via the intercalated cells $(14,15)$. However, the striking morphologic differences between inner stripe principal cells and principal cells found in turtle bladder and cortical collecting duct (13) makes it hazardous to assign functions to the inner stripe principal cell based on direct analogy to these other tissues. There is also direct evidence that inner stripe principal cells participate in acidification. Thus, Dobyan et al. (34) have shown that all of the cells in this segment stain positively for carbonic anhydrase. In addition, Koeppen (17), using intracellular elec- 
trodes in isolated perfused rabbit collecting ducts, has found a single cell type in this segment by electrophysiologic criteria; using similar methods, two cell types have been described in outer stripe and cortical collecting ducts (35). Morphologically, principal cells in the inner stripe resemble those found in the papillary collecting duct. In the papilla, acid secretion is believed to occur despite the absence of intercalated cells $(36,37)$. Thus, the fact that the cells in the present study are principal cells does not preclude their participation in acid secretion in vivo.

Because cells in suspension are oriented randomly, we could not examine directly the apical or basolateral locations of $\mathrm{H}^{+}$ transport. Since coupled extrusion of alkali and $\mathrm{H}^{+}$from the cells would have obscured both intra and extracellular $\mathrm{pH}$ changes, we acid loaded the cells, thereby stimulating $\mathrm{H}^{+}$transport almost exclusively. In addition, it was anticipated that omission of $\mathrm{HCO}_{3}^{-}$would further diminish net alkali transport.

The observations that neither removal of extracellular sodium (Fig. 7) nor treatment with amiloride inhibited $\mathrm{pH}_{\mathrm{i}}$ recovery provide evidence that $\mathrm{Na}^{+} / \mathrm{H}^{+}$exchange does not participate $\mathrm{pH}_{\mathrm{i}}$ regulation in this preparation. Indeed, MCD cells may not have $\mathrm{Na}^{+} / \mathrm{H}^{+}$exchangers on their plasma membranes in situ. Consistent with this hypothesis, bicarbonate reabsorption in isolated perfused rabbit MCD was not inhibited either by removal of luminal sodium or by luminal amiloride (11). In addition, in this same preparation, neither net sodium reabsorption nor secretion has been detectable (38).

Consistent with the fact that the mammalian medulla functions in a relatively anaerobic environment, the MCD has been shown in this study (Fig. 4) and others (27) to have a high glycolytic capacity. In the present study cells poisoned with $\mathrm{KCN}$ in the presence of glucose supported $\mathrm{pH}_{\mathrm{i}}$ recovery rates indistinguishable from those of unpoisoned cells. These results suggest that $\mathrm{MCD}$ cells can regulate $\mathrm{pH}_{\mathrm{i}}$, and presumably can secrete protons under anaerobic conditions, energized by glycolysis alone.

As outlined in the introduction, a plasma membrane protonATPase has been demonstrated to mediate proton secretion in the turtle bladder. Due to functional and morphological similarities between the two tissues, luminal acidification in the mammalian MCD has also been attributed to a plasma membrane proton-ATPase. Our results using purified suspensions of rabbit MCD cells provide further direct evidence for a role for such a plasma membrane proton-ATPase in transmembrane proton transport and $\mathrm{pH}_{\mathrm{i}}$ regulation. We have demonstrated that the recovery of $\mathrm{pH}_{\mathrm{i}}$ from acid loading is inhibited by depletion of cellular ATP (Figs. 2, 4, and 5; Table I) and by exposure of the cells to $N$-ethyl maleimide, a potent but nonspecific inhibitor of proton-ATPases (Table II). In addition, the rate of acid extrusion from the cells is ATP dependent (Fig. 9). Finally, conditions that evoke acid extrusion result in measurable depletion of cellular ATP stores.

\section{Acknowlegments}

We thank Robert Fuhro and Robert Lufburrow III for their outstanding technical assistance, Drs. Lloyd Cantley and Stephanie Lear for their help with the cell preparations, Michelle Hardiman for excellent secretarial assistance, Dr. H. Franklin Bunn for the use of the fluorimeter, and Dr. William Silen for the use of the $\mathrm{pH}$ stat.

This work was supported by National Institutes of Health (NIH) New Investigator Research Award 31983 (to Dr. Seifter) and NIH grant AM 18078 (awarded to Dr. Silva); Dr. Zeidel was the recipient of NIH training fellowship AM 07214-01.

\section{References}

1. Al-Awqati, Q., A. Mueller, and P. R. Steinmetz. 1977. Transport of $\mathrm{H}^{+}$against electrochemical gradients in turtle urinary bladder. $\mathrm{Am}$. J. Physiol. 322:F502-F508.

2. Dixon, T. E., and Q. Al-Awqati. 1979. Urinary acification in turtle bladder is due to a reversible proton-translocating ATPase. Proc. Natl. Acad. Sci. USA. 76:3135-3138.

3. Dixon, T. E., and Q. Al-Awqati. 1980. $\mathrm{H}^{+} /$ATP Stoichiometry of proton pump of turtle urinary bladder. J. Biol. Chem. 255:3237-3239.

4. Beauwens, R., and Q. Al-Awqati. 1976. Active $\mathrm{H}^{+}$transport in the turtle urinary bladder. J. Gen. Physiol. 68:421-439.

5. Steinmetz, P. R., R. F. Husted, A. Mueller, and R. Beauwens. 1981. Coupling between $\mathrm{H}^{+}$transport and ahaerobic glycolysis in turtle urinary bladder: effects of inhibitors of $\mathrm{H}^{+}$ATPase. J. Membr. Biol. 59: 27-34.

6. Gluck, S., S. Kelly, and Q. Al-Awqati. 1982. The proton translocating ATPase responsible for urinary acidification. J. Biol. Chem. 257:9230-9233.

7. Steinmetz, P. R. 1974. Cellular mechanisms of urinary acidification. Physiol. Rev. 54:890-956.

8. Lefevre, M. E. 1973. Effects of aldosterone on the isolated substratedepleted turtle bladder. Am. J. Physiol. 255:1252-1256.

9. Stone, D. K., D. W. Seldin, J. P. Kokko, and H. R. Jacobson. 1983. Anion dependence of rabbit medullary collecting duct acidification. J. Clin. Invest. 71:1505-1508.

10. Lombard, W. E., J. P. Kokko, and H. R. Jacobson. 1983. Bicarbonate transport in cortical and outer medullary collecting tubules. Am. J. Physiol. 244:F289-F296.

11. Stone, D. K., D. W. Seldin, J. P. Kokko, and H. R. Jacobson. 1983. Mineralocorticoid modulation of rabbit medullary collecting duct acidification. A sodium-independent effect. J. Clin. Invest. 72:2050-2059.

12. Gluck, S., and Q. Al-Awqati. 1984. An electrogenic proton translocating ATPase from bovine kidney medulla. J. Clin. Invest. 73:17041710.

13. Kaissling, B., and W. Kriz. 1976. Structural analysis of the rabbit kidney. Adv. Anat. Embryol. Cell. Biol. 56:1-121.

14. Madsen, K. M., and C. C. Tisher. 1984. Response of intercalated cells of rat outer medullary collecting duct of chronic metabolic acidosis. Lab. Invest. 51:268-276.

15. Madsen, K. M., and C. C. Tisher. 1983. Cellular response to acute respiratory acidosis in rat medullary collecting duct. Am. J. Physiol. 245:F670-F679.

16. Stetson, D. L, and P. R. Steinmetz. 1983. Role of membrane fusion in $\mathrm{CO}_{2}$ stimulation of proton secretion by turtle bladder. $\mathrm{Am}$. J. Physiol. 245:C113-C120.

17. Koeppen, B. M. 1985. Conductive properties of the rabbit outer medullary collecting duct: inner stripe. Am. J. Physiol. 248:F500-F506,

18. Eveloff, J., W. Haase, and R. Kinne. 1980. Separation of renal medullary cells: isolation of cells from thick ascending limb of Henle's loop. J. Cell. Biol. 87:672-681.

19. Silva, P. S., M. A. Klausner, F. D. Segall, S. Rosen, M. L. Zeidel, and J. Seifter. Isolation of medullary collecting tubular cells. Submitted for publication.

20. Thomas, J. A., R. N. Buchsbaum, A. Simniak, and E. Racker. 1979. Intracellular $\mathrm{pH}$ measurements in Ehrlich ascites tumor cells utilizing spectroscopic probes generated in situ. Biochemistry. 18:22102218.

21. Thomas, J. A., P. C. Kolbech, and T. A. Langworth. 1981. Measurement of intracellular $\mathrm{pH}$ with spectroscopic probes generated in situ. In Intracellular pH: Its Measurement, Regulation, and Utilization in Cellular Functions. R. Nuccitelli and D. Deamer, editors. Alan R. Liss, New York. 115-129.

22. Babcock, D. F. 1983. Examination of the intracellular ionic environment and of ionophore action by null point measurement employing the fluorescein chromophore. J. Biol. Chem. 258:6380-6389. 
23. Kimmich, G. A., J. Randles, and J. S. Brand. 1975. Assay of picomole amounts of ATP, ADP, and AMP using the luciferase system. Anal. Biochem. 69:187-206.

24. Bowen, J., and C. Levinson. 1984. pH regulation of Ehrlich ascites tumor cells. J. Membr. Biol. 79:7-18.

25. Roos, A., and W. F. Boron. 1981. Intracellular pH. Physiol. Rev. 61:296-434.

26. Boron, W. F., and P. DeWeer. 1976. Intracellular $\mathrm{Ph}$ transients in squid giant axons caused by $\mathrm{CO}_{2}, \mathrm{NH}_{3}$, and metabolic inhibitors. $J$. Gen. Physiol. 67:91-112.

27. Guder; W. G., and B. D. Ross. 1984. Enzyme distribution along the nephron. Kidney Int. 26:101-111.

28. Benos, D. J. 1982. Amiloride: a molecular probe of sodium transport in tissues and cells. Am. J. Physiol. 242:C131-C145.

29. Stone, D. S., W. S. Xie, and E. Racker. 1983. An ATP-driven proton pump in clathrin-coated vesicles. J. Biol. Chem. 258:4059-4062.

30. Grinstein, S. A., A. Rothstein, B. Sarkadi, and E. W. Gelfand. 1984. Responses of lymphocytes to anisotonic media: volume-regulating behavior. Am. J. Physiol. 246:C204-C215.
31. Busa, W. B., and R. Nuccitelli. 1984. Metabolic regulation via intracellular pH. Am. J. Physiol. 246:R409-R438.

32. Ives, H. E., and F. C. Rector. 1984. Proton transport and cell function. J. Clin. Invest. 73:285-290.

33. Pollock, A. S. 1984. Intracellular pH of hepatocytes in primary monolayer culture. Am. J. Physiol. 246:F738-F744.

34. Dobyan, D. C., L. S. Magill, P. A. Friedman, S. C. Hebert, and R. E. Bulger. 1982. Carbonic anhydrase histochemistry in rabbit and mouse kidneys. Anat. Rec. 204:185-197.

35. O’Neil; R. G., and S. C. Sansom. 1984. Electrophysiological properties of cellular and paracellular conductive pathways of the rabbit cortical collecting duct. J. Membr. biol. 82:281-295.

36. Ullrich, K. J., and F. Papavassiliou. 1981. Bicarbonate reabsorption in the papillary collecting duct of rats. Pflüegers Arch. Eur. J. Physiol. 389:271-275.

37. Graber, M. L., H. H. Bengele, J. H. Schwartz, and E. A. Alexander. 1981. pH and $\mathrm{PCO}_{2}$ profiles of the rat inner medullary collecting duct. Am. J. Physiol. 241:F659-F668.

38. Stokes, J. B. 1982. Ion transport by the cortical and outer medullary collecting tubule. Kidney Int. 22:473-484. 